\title{
Investigations on periphytic algae: comparing distinct years in the presence and absence of submerged macrophytes
}

\author{
Neif, EM. ${ }^{a *}$, Behrend, RDL. ${ }^{a}$ and Rodrigues, L. ${ }^{a, b}$ \\ aPrograma de Pós-graduação em Ecologia de Ambientes Aquáticos Continentais - PEA, \\ Universidade Estadual de Maringá - UEM, Av. Colombo, 5790, Jd. Universitário, CEP 87020-900, Maringá, PR, Brazil \\ ${ }^{\text {b}}$ Departamento de Biologia, Núcleo de Pesquisas em Limnologia, Ictiologia e Aqüicultura - Nupélia, \\ Universidade Estadual de Maringá - UEM, Av. Colombo, 5790, CEP 87020-900, Maringá, PR, Brazil \\ *e-mail: neif.erika@gmail.com
}

Received August 6, 2013 -Accepted August 13, 2013 - Distributed May 31, 2014

Aquatic macrophytes provide physical structure, increase complexity and habitat structure, and affect many groups of organisms (Mormul et al., 2010), specially algae (Biolo and Rodrigues, 2013). So, the more complex and structured a habitat, the higher the number of species present.

In the upper Parana River floodplain, submerged macrophytes have become dominant. Previously, Eichhornia azurea Kunth was the most important and dominant substrate of epiphytic algae. Thus, it is believed that proliferation and abundance of submerged macrophytes altered the composition and richness of epiphytic algae, both in lentic and lotic enviroments, and on the E. azurea substrate.

This contribution aims compare the species of epiphytic algae in distinct substrates in 2000 (submerged macrophytes absent) and 2009 (submerged macrophytes present), in distinct environments of the upper Paraná River floodplain. So, we intend to verify if the presence of submerged macrophytes altered the epiphytic algae species, as well as increased its species richness.

Two environments of the upper Parana River floodplain, Pombas lake (22 $47^{\prime}$ 'S; $\left.53^{\circ} 21^{\prime \prime} \mathrm{W}\right)$ and Cortado channel ( $22^{\circ} 48^{\prime \prime}$; $\left.53^{\circ} 22^{\prime \prime} \mathrm{W}\right)$ were sampled. These environments were characterised by dominance of emergent macrophyte Eichhornia azurea Kunth in 2000. In 2009, they started to present dense stands of submerged macrophytes.

Petioles of the emergent macrophyte Eichhornia azurea Kunth were sampled in both years, but parts of submerged macrophytes (Egeria najas and Hydrilla verticillata) not found in 2000, were sampled in 2009. The periphytic material was removed from a known area of the petioles and stems, respectively. We only used in analysis, species that could be identified to species level. Kruskal Wallis test $(p<0,05)$ was used to test separately differences in richness of epiphytic algae community among sampled years and types of substrates. To test species specificity to substrate complexity and years, we use Indval (Dufrêne and Legendre, 1997).

We found 123 taxa. In 2000, 85 taxa were present, whereas in 2009, 111 taxa. Species found in both years represented 74 taxa $(60.2 \%$ of total). We also noted that 12 species $(9.75 \%)$ were only present in 2000 , whereas 37 only appeared in 2009 (30.1\%). Of this total, 18 species (48.6\%) were only encountered in submerged species, and five species were only presents in emergent. Significant differences in species richness among substrates were verified according Kruskall-Wallis test $(\mathrm{KW}(11 ; 24)=21.56 ; \mathrm{p}<0.01)$.

In relation to taxa only recorded in E. azurea in 2000 and 2009, all of species were weakly attached algae. The indicator value (IndVal) of species was significant $(p<0.05)$ for five species presents in E. azurea substrate in 2000 (Table 1). Regarding submerged plants, it was registered presence of 13 weakly attached algae.

Submerged macrophytes, especially E. najas, presented the highest number of taxa and together with $H$. verticillatta, they were responsible for the appearance of new taxa, because they increase habitat complexity. Thus, architecture of plants provides a higher range of micro-habitats, which favours new areas for colonisation, and refuge from predators (Biolo and Rodrigues, 2013).

Lower richness of weakly attached algae in 2009 was verified for E. azurea substrate, in relation to 2000 . Nevertheless, submerged plants presented several species of these algae in 2009, contributing to the increasing of species richness of epiphytic algae. Among other groups of weakly attached algae, it is worth noting the Zygnemaphyceae class, which according to Murakami et al. (2009), are favoured in environments with a high quantity of macrophytes.

It was verified that rare species found in 2000 possessed morphological adaptations (thorns, branch), but it was not verified in 2009. So, we can presume that these structures allowed species to attach to substrates and/or protect itself against herbivory. It is worth emphasising that the conditions of water flow for the Paraná River in 2000 were different from conditions found in 2009. The presence of submerged macrophytes altered the composition of epiphytic algae community, as well as increased its species richness.

We consider, however, the need to continue to use the emergent macrophyte $E$. azurea in biomonitoring of the upper Paraná River floodplain, because this plant is an important substrate for epiphytic algae. Moreover, future research are extremely important to verify what is the main factor acting on increase of richness of epiphytic algae, especially the weakly attached algae: alterations of abiotic variables or increase of habitat complexity in function of submerged macrophytes. 
Table 1. Rare species recorded in 2000 and 2009, in emergent macrophyte (Eichhornia azurea) and in submerged macrophyte (Egeria najas and Hydrilla verticillata). Numbers represent species with IndVal significant.

\begin{tabular}{|c|c|c|}
\hline Taxa only recorded in 2000 & \multicolumn{2}{|c|}{ Taxa only recorded in 2009} \\
\hline Eichhornia azurea & Eichhornia azurea & Submerged \\
\hline${ }^{1}$ Desmodesmus brasiliensis* & Ankistrodesmus falcatus* & Hydrosera whampoensis \\
\hline D. denticulatus $*$ & Cosmarium baileyi* & Nitzschia lineares \\
\hline Dictyosphaerium pulchellum * & C. porrectum* & Pinnularia cf doeringii \\
\hline Scenedesmus seelyanum* & C. vexatum* & Surilella lineares \\
\hline${ }^{2}$ Selenastrum gracile* & Desmodesmus communis* & Surilella cf robusta \\
\hline Micrasterias truncata* & & Coelastrum microporum * \\
\hline Octacanthium mucronulatum* & & Scenesdesmus cf acutus * \\
\hline${ }^{3}$ Staurastrum hirsutum* & & Scenedesmus cf gutwiskii * \\
\hline S. leptocladum* & & Scenedesmus cf spinosus * \\
\hline S. setigerum* $*$ & & Closterium incurvum $*$ \\
\hline${ }^{4}$ Staurodesmus dejectus ${ }^{*}$ & & Closterium cf incurvum var* \\
\hline${ }^{5}$ S. dickiei* & & Closterium navicula* \\
\hline & & Cosmarium punctulatum* \\
\hline & & Cosmarium subspeciosum* \\
\hline & & Euastrum cf abruptum var* \\
\hline & & Micrasterias cf abrupta* \\
\hline & & Micrasterias mahabuleshwarensis * \\
\hline & & Micrasterias rotata $*$ \\
\hline
\end{tabular}

$*=$ weakly attached species.

\section{References}

BIOLO, S. and RODRIGUES, L., 2013. Comparison of the structure of the periphytic community in distinct substrates from a neotropical floodplain. International Research Journal of Plant Science, vol. 4, no. 3, p. 64-75.

DUFRÊNE, M. and LEGENDRE, P., 1997. Species assemblages and indicator species: the need for a flexible asymmetrical approach. Ecological Monographs, vol. 67, no. 3, p. 345-366.
MORMUL, RP., THOMAZ, SM., SILVEIRA, MJ. and RODRIGUES, L., 2010. Epiphyton or macrophyte: which primary producer attracts the snail Hebetancylus moricandi? American Malacological Bulletin, vol. 28, no. 1-2, p. 127-133. http://dx.doi.org/10.4003/006.028.0205.

MURAKAMI, EA., BICUDO, DC. and RODRIGUES, L., 2009. Periphytic algae of the Garças Lake, Upper Paraná River floodplain: comparing the years 1994 and 2004. Brazilian Journal of Biology, vol. 69, no. 2, sup. Suppl, p. 459-468. http://dx.doi.org/10.1590/ S1519-69842009000300002. PMid:19738955 